\title{
11
}

\section{THE POLITICS OF EVIDENCE- BASED ADVOCACY BY CIVIL SOCIETY ORGANISATIONS}

Margit van Wessel

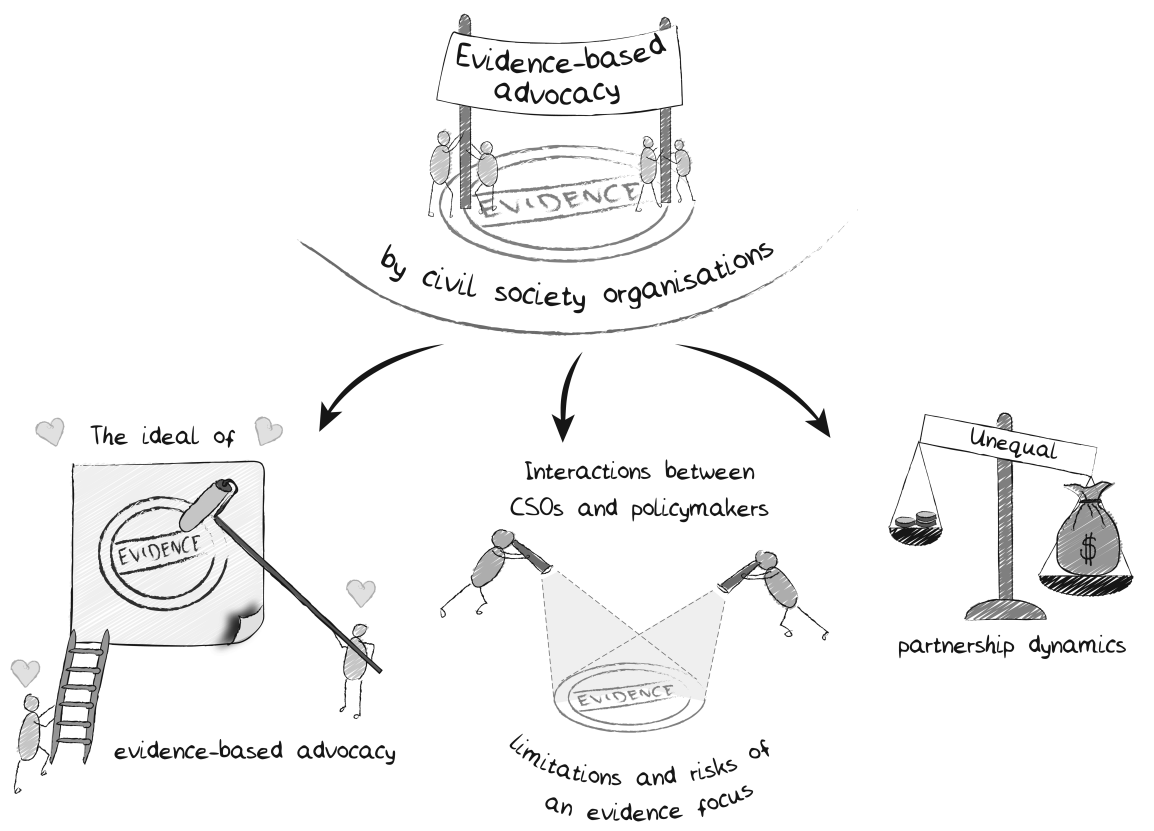

\section{Introduction}

This chapter discusses the nature and role of evidence in advocacy for development by civil society organisations (CSOs). It focuses on the ways the production and use of evidence in this context should be understood: as relational, dynamic, and political, with important implications for whether, and 
how, different forms of evidence can come to be seen and taken into account. After showing the important and diverse roles of evidence in CSO advocacy, this chapter problematises the supposed objectivity of evidence and the neutral nature of its usage, as well as the implications for inclusive development. It does this by identifying the ways in which evidence creation and usage is shaped in relational dynamics between CSOs and the policymakers they target, and between CSOs that are differently positioned in power relations. The chapter further considers the implications of these issues for inclusion, ownership, representation, and legitimacy, and presents possible advances based on these insights.

\section{The ideal of evidence-based advocacy}

Over the past two decades, the ideal of 'evidence-based policymaking' has been firmly established across policy domains and policymaking arenas (Parkhurst, 2017), including international development. Evidence-based policymaking has found its way into practice and legitimation processes, through an increased focus on 'what works,' results, efficiency, and accountability in development (Anderson, 2010; Goldman and Pabari, 2021; Hayman, 2016, p. 131; Storeng and Béhague, 2014). Leading international development think tank Overseas Development Institute (ODI) exemplifies the weight prominent actors in the sector give to this ideal in a report promoting evidencebased working:

Better use of evidence by CSOs is part of the solution to increasing the policy influence and pro-poor impact of their work. Better utilisation of research and evidence in development policy and practice can help save lives, reduce poverty and improve the quality of life $[. .$.$] In order to have a$ greater impact, civil society must improve their interaction with, and effect on, public institutions, actors and policies - and do so based on rigorous evidence.

(Court et al., 2006, p. 1)

This statement speaks directly to CSOs involved in advocacy for development, defined in this chapter as a 'wide range of activities conducted to influence decision-makers at different levels, with the overall aim of combatting the structural causes of poverty and injustice' (Barrett et al., 2016). The definition follows the widely held belief that CSO advocacy is a tool to fight the causes of poverty and injustice and influence structural change, aiming to alter social, political, and policy structures that sustain inequalities (ibid). Policymakers are a key target of many CSOs' advocacy for development, with the diverse roles for evidence widely embraced by the latter.

Evidence was already fundamental to civil society advocacy in the context of international development before the advent of the evidence-based policy 
movement. Early leading publications emphasised the prominent role of information, mainly in the shape of information politics, or 'the ability to quickly and credibly generate information and move it where it will have the most impact' (Keck and Sikkink, 1999, p. 95); Jordan and Van Tuijl (1998, p. 2052) go so far as to define advocacy as 'an act of organizing the strategic use of information to democratize unequal power relations.'

While some CSOs give it a more prominent role than others, 'evidence-based advocacy' is a common strategy. To illustrate: websites of leading CSOs in international development commonly show that they have adopted not only working with information but also the language of evidence-based policy, commonly stating 'evidence' as fundamental to their advocacy.

Evidence can take multiple forms. CSOs carry out research of their own, or may hire dedicated experts (Eagleton-Pierce, 2015). Research is also commonly carried out through collaborations, such as between 'Northern' and 'Southern' CSO partners, between CSOs and universities, and by CSO networks (Travers, 2016). Research can be on local or regional realities in the Global South (Motta and Nilsen, 2011); on international or global dimensions of issues (EagletonPierce, 2015); or combinations of both, as when global issues like climate change or land grabbing are illustrated by case studies of local realities or solutions (Arensman et al., 2015). Research can involve new data, or centre on synthesis of existing data and analyses. In addition, research can also centre on the humanisation and concretisation of issues and their solutions by testimony and visuals, bringing in the 'voices' of those affected.

Evidence can come in with advocacy in different stages of policymaking. It can play a role in agenda-setting, policy formulation, implementation, and evaluation (Court et al., 2006). However, relatively much of the effort and influence of advocacy appears to lie in agenda-setting, with CSOs seeking to draw attention to specific problems and solutions; proposing understandings of their nature and importance; and seeking to advance their political salience to policymakers by embedding CSOs' voices into policy processes (Arensman et al., 2015, p. 584-585).

Research on evidence-based advocacy by CSOs mostly shows roles in agendasetting (Arensman et al., 2018; Arensman et al., 2015; Eagleton-Pierce, 2015). Some research also shows roles of evidence in advocacy by CSOs towards policy formulation, seeking uptake of CSO ideas and results - particularly once CSOs have succeeded in establishing themselves as valuable partners and their agendas as agreeable (Stroup and Wong, 2017). CSO advocacy addressing policy implementation and evaluation has been less researched (but see Barnes et al., 2016 for an example), so we know little of the role of evidence in that. However, many CSOs active in service delivery may seek to influence policy through the entry points provided by such roles, as some research at least indicates (Van Wessel et al., 2019), and evidence may be important here. This is of particular interest with civic space for CSO advocacy increasingly constricted in many contexts (CIVICUS, 2020). 


\section{Using evidence: different strategies and approaches}

Much of the emphasis on agenda-setting in civil society advocacy can be illustrated by pointing out how CSOs in international development commonly seek to attain a voice for relatively marginalised groups, and their understandings, agendas, and solutions. For civil society, it takes multiple actions and often significant time before advocacy can move from agenda-setting into contributing to actual policy formulation and beyond. Evidence can thus support efforts to gain access and close contact with policymakers and other audiences, which has strategic significance for the way evidence is employed. CSOs' engagement with questions of evidence can be relatively open ended, seeking to identify and understand issues that may subsequently guide advocacy (Gooding, 2016; Travers, 2016). However, evidence creation, interpretation, and use are often guided by strategic considerations: evidence is commonly brought in to back up and legitimate established positions (Gooding, 2016; Mably, 2006; Thrandardottir, 2016). Evidence is thus employed to convince policymakers and others of truth claims, rather than to facilitate learning based on unbiased consideration of the best available information. Evidence is utilised to convince policymakers of the nature of an issue and its effects on specific groups or public goods; its pressing nature; the nature of its causes; the effectiveness of certain solutions; or the way current policies or forms of implementation are wanting. This last use of evidence is very visible in campaigning, as in Oxfam's use of what it calls 'killer facts' to provoke, draw attention, mobilise, and set agendas on issues such as economic inequality (Oxfam, 2019).

Another format, the case study, illustrates a problem and/or its solution by presenting exemplars for upscaling (often by the State), such as Hivos' case study of Sumba Island-meant to inspire actors elsewhere by proposing an exemplary way of reducing communities' dependency on fossil fuel, while developing access to locally produced renewable energy (Hivos, 2016).

Evidence can thus be central to advocacy in different ways. At the same time, CSOs have different approaches when it comes to the role of evidence in their advocacy. While some, like Oxfam, take an activist stance, openly employing evidence for supporting truth claims and explicit attempts at influencing, others rather take the stance of being a relatively neutral provider of information. Fundamental underlying values and missions may then take a back seat in communications, relatively speaking, as can be seen in the case of African Child Policy Forum (ACPF). ACPF positions itself primarily through its research, providing policy-relevant information and recommendations for policymakers. ACPF is appreciated among key target actors for performing this role, and is a sought-after knowledge partner. At the same time, by performing this role, ACPF does voice concerns and plays the role of an agenda-setter (Arensman et al., 2015; Arensman et al., 2018). The boundaries between activist and knowledge provider roles thus seem fluid. In any case, CSOs acting from both such stances are faced with the same need to build and maintain credibility with policymakers when it comes to the evidence they 


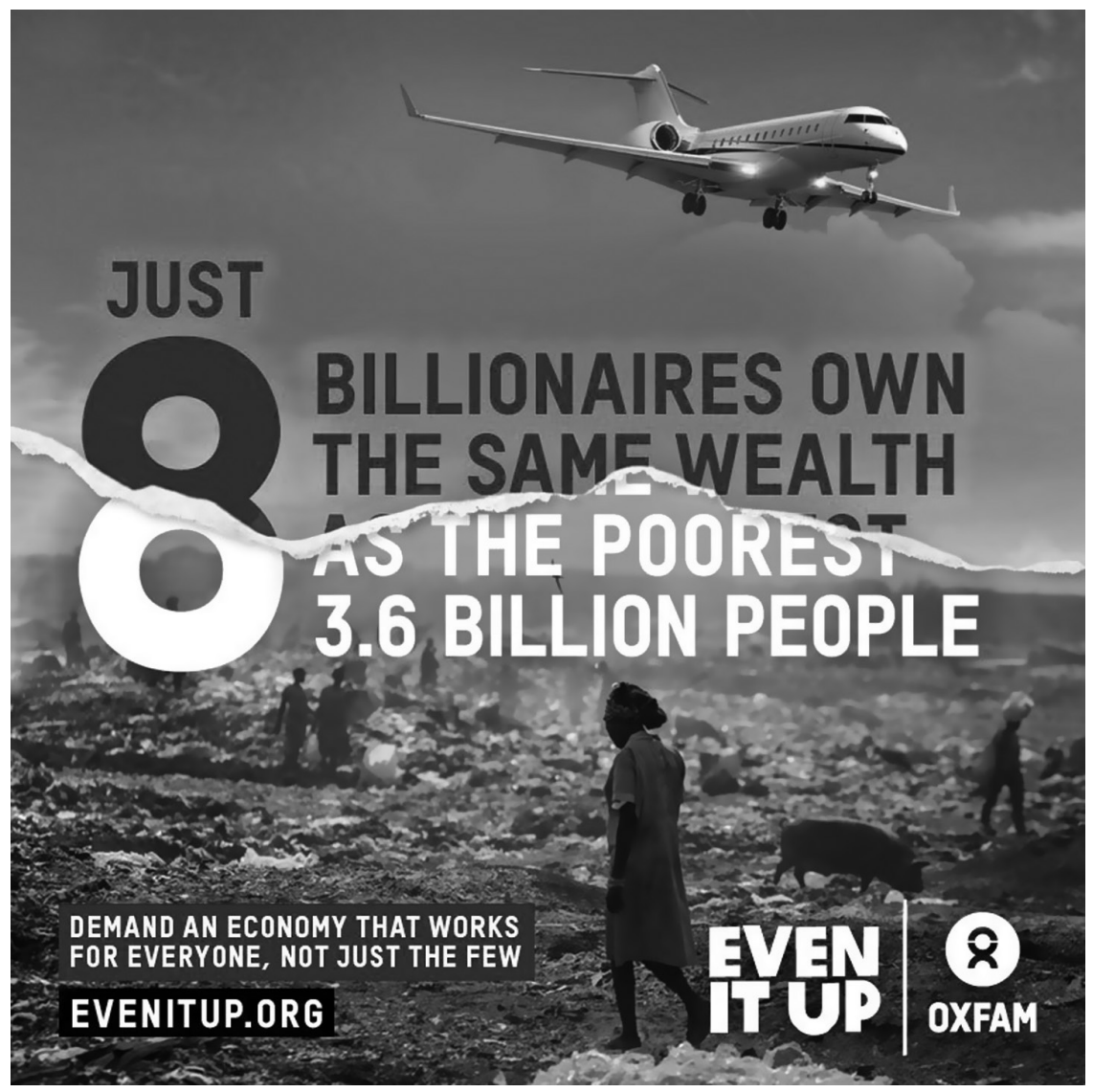

FIGURE 11.1 Oxfam's usage of evidence as 'killer facts.' Source: https://oxfamblogs.o $\mathrm{rg} / \mathrm{fp} 2 \mathrm{p} / 8$-men-now-own-the-same-as-the-poorest-half-of-the-world-t he-davos-killer-fact-just-got-more-deadly/

advance. When accepted as credible, CSOs can be attractive interlocutors for policymakers because of the information they can provide on problems, solutions, and constituencies' views; as experts providing quality policy analyses; and as organisations having privileged access to information 'from the ground up' (Tallberg et al., 2018; Travers, 2016; Van Wessel et al., 2017). Doing so successfully can help them fulfil policymakers' needs, while advancing their own agendas.

\section{Interactions between CSOs and policymakers: limitations and risks of an evidence focus}

Literature discussing evidence-based advocacy by CSOs commonly stresses their capacity to provide convincing information to policymakers, rooted 


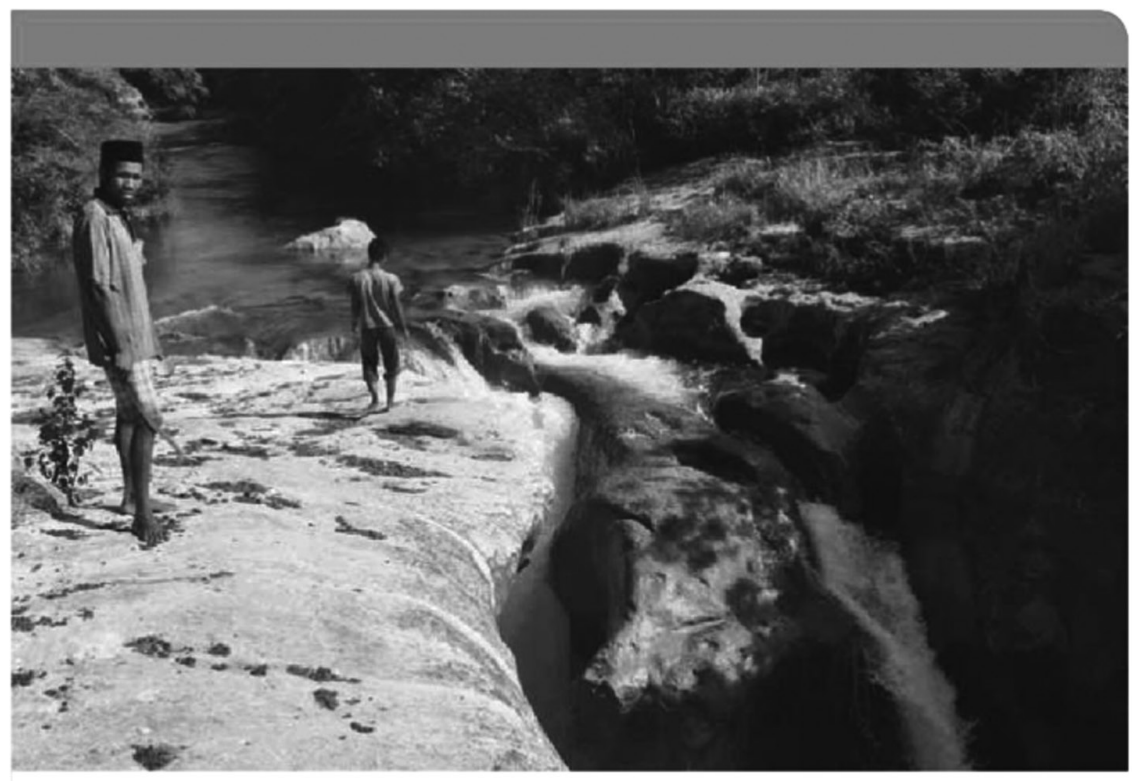

\section{SUMBA: AN ICONIC ISLAND TO DEMONSTRATE THE POTENTIAL OF RENEWABLE ENERGY}

Poverty reduction, economic development and energy access combined

FIGURE 11.2 Hivos' usage of an exemplar. Source: https://issuu.com/hivos/docs/b rochuresumba_iconic_island 
in engagement with policy process and practices and digestibly packaged. Policymaking is presented as a rational process, with the quality of evidence and objectivity both playing key roles (Court et al., 2006; Mably, 2006).

However, these requirements can also constrict civil society advocacy by narrowing its scope. Storeng and Béhague (2014) show how international maternal health advocacy has evolved from drawing on feminist and social justice arguments for legitimation, to using number-based evidence on maternal mortality or morbidity rates, and the cost-effectiveness of targeted interventions. This shift has contributed to the depoliticisation of the issue, while constricting valuable knowledge to whatever is measurable: policymakers can thus be convinced of targeted interventions' effectiveness, rather than of broader transformations. This is an example of 'issue bias' that 'can arise when promotion of evidence skews agendas to those issues which are measured rather than those which are important to affected populations' (Parkhurst, 2017, p. 28).

Privileging 'expertise' as objective can similarly hamper representation. Rodriguez (2010), writing on a global policy process on migration and development, shows how civil society was brought into the arena to represent migrantsyet organisers privileged selected 'experts,' who provided knowledge much more fitting to the interests of states and corporate actors than those of critical grassroots migrant organisations, whose knowledge was excluded. By affecting creation, selection, and interpretation of evidence (Parkhurst, 2017) that can be used to identify and address policy questions, the foundations of policy processes can be affected: What are people's exact needs? Which needs matter most? Asking for what kind of policy or policy change?

Other research argues that the role of evidence in civil society advocacy is relative, with evidence much less in the lead than one might think looking at the status that it is commonly accorded. First, an approach to civil society advocacy that puts provision of quality evidence at the heart of advocacy work easily reduces it to an effort centred on the expertise policymakers ostensibly value CSOs for, ignoring the complex nature of advocacy. It does not acknowledge the strategic nature of advocacy, which in important ways rests on the capacity to monitor and engage with political dynamics (Arensman et al., 2015), build and maintain relations with targets, allies, constituencies, and publics (Barnes et al., 2016; Motta and Nilsen, 2011), and create and benefit from opportunities (Barrett et al., 2016).

Such an approach may also ignore the fact that advocacy need not centre on provision of evidence. Keck and Sikkink (1999), for example, also identify accountability politics (holding targets to account, appealing to norms or laws such as human rights); symbolic politics (involving organising around symbols of systematic injustice such as the killing of George Floyd); and leverage politics (drawing on CSOs' ability to call upon powerful actors to affect a situation where weaker members of a network are unlikely to have sufficient influence, such as Dutch NGOs appealing to the Dutch state to influence another state where partner CSOs within that country are helped with that influence). For 
example, Dutch CSOs working with CSO partners in Nigeria working on oil pollution might ask the Dutch government to try and use its influence with the Nigerian government concerning the management of pollution caused by oil production in which Shell has been involved, using information provided by Nigerian partners.

Second, an approach to civil society advocacy that puts provision of quality evidence at the heart of the work also ignores the way policymakers operate. Policymakers often do not approach evidence or its providers neutrally, limiting the chances of objective evidence playing a leading role. The likelihood of engagement with CSOs' evidence, and the CSOs providing it, thus seems higher when there is agreement between CSO and policymaker views (Mably, 2006; Parkhurst, 2017; Rodriquez, 2010; Weible, 2008). Additionally, Gourevitch and Young (2012) show that CSOs' resources for credibility are varied, including virtue, common interest with audiences, and being subjected to verification. The role of evidence is thus relative. This is in line with broader literature on the role of evidence in policymaking that shows that knowledge use in policymaking is shaped in political process (Keeley and Scoones, 2014; Parkhurst, 2017). The actual importance of evidence and its objectivity is therefore open to questioning, as are the conditions under which evidence is afforded objectivity by policymakers.

Third, evidence creation, interpretation, and use are a result of dynamics between CSOs and their targets. Mayne et al. (2018) consider how, for Oxfam, these dynamics shape their way of working with evidence. For Oxfam, evidence is integrated into influencing strategies that involve closely engaging with specific policy processes; designing evidence to maximise influence; designing and using additional influencing strategies; adapting the presentation of evidence and influencing strategies to changing contexts; and embracing trial and error.

The capacity to use evidence in advocacy thus concerns not only evidence as such, but also the development and execution of effective advocacy strategies in political interaction with targets. Eagleton-Pierce (2015), writing on Oxfam's trade policy advocacy, describes as a key strategy its connecting with sanctioned knowledge in the World Trade Organisation's context, i.e. working with theories, principles, modes of reasoning, agendas, and histories connected to trade policymaking. Being able to relate to economics and law as key academic fields proved important to develop their access-and therefore, exercising a form of power. Eagleton-Pierce (2015, p. 163) further explains that 'the Oxfam writer is traditionally imbued with a social justice sensibility, including a capacity to unearth and trace forms of human suffering beneath a veneer of orthodox knowledge,' and that 'pure forms of economic and legal knowledge are not the only sources of symbolic power that are nurtured by Oxfam authors to mount their trade campaigns. We also see explicit and tacit appeals to other systems and techniques of legitimation, notably Christian values of care and compassion for "distant suffering" beyond the West.' 
Even when employing differentiated and contextualised influencing strategies, civil society advocacy is still shaped by the readiness of targets to allow them an influencing role. This can relativise the role of evidence by shaping the way CSOs conduct their advocacy. Stroup and Wong (2017) seek to explain how it is that only a very small number of INGOs (International Non-Governmental Organisations) are highly influential, and how this position then traps them into roles of advocates for moderate change, shaping their strategies to this effect. They argue that the leading role of certain INGOs depends on their authority: the deference they have managed to secure from multiple audiences. In their analysis, authority is relational, built up over time, and involves audiences (such as states) stopping, over time, 'evaluating the merits of every single case' (Stroup and Wong, 2017, p. 27). To maintain this status, leading INGOs need to moderate their demands making authority a 'trap,' leading only to incremental 'vanilla victories,' as the authors describe it. In this view, authority implies a limited role for evidence as a source of influence (even though repeated persuasion, as by evidence, can result in deference to the INGO).

\section{Unequal partnership dynamics}

The lion's share of development funding for civil society is controlled by CSOs in the Global North. In 2018, less than 4\% of international funding for humanitarian assistance went to local and domestic CSOs (Development Initiatives, 2019). This means that a very small subgroup of CSOs-INGOs that are mostly Northern-based - control by far the most resources for evidence-building, interpretation, and use for advocacy in the context of international development. This likely contributes to a phenomenon described by Hayman (2016) and Fransman (2019): a global push towards rigorous, expertise-intensive research as a form of evidence, with advantages for those having the capacity to provide such evidence. As Court et al. (2006, p. 20) state, 'CSOs have significant constraints on technical and financial capacities that can limit their ability to engage with policy processes and use evidence effectively,' further noting that 'given their resources, big international NGOs sometimes crowd out the voices of smaller, indigenous ones.' However, this dominance is a complicated matter, involving a range of ways in which ties between CSOs shape the role of evidence in advocacy.

INGOs are closely involved with evidence-building in the Global South. Much of the research they commission and carry out is conducted in the countries where they work (often through partners, consultants, and/or national-level chapters of their organisations), as these are the sites where problems are being experienced, and in which locally viable solutions need to be built. In addition, Southern-based case studies, exemplars, and testimony are helpful to build policy-relevant knowledge and persuasive arguments (Travers, 2016, p. 115). This includes forms of evidence beyond research. Southern-based knowledge in the form of testimony, case studies, and visuals also helps build persuasive cases targeting Northern states and international institutions. 
For example, Eagleton-Pierce (2015, p.164), writing on Oxfam's reporting on trade policy, points out the 'use of select quotes (along with photographs) from the field, whereby the voice of a farmer or producer helps to justify the overall argument.' Their privileged access to local partners and constituencies can further build up INGOs' reputation as actors having access to important development knowledge 'from the ground' (Van Wessel et al., 2017), contributing to their credibility and access to policymakers.

Well-resourced INGOs often also seek to facilitate participation of Southern CSOs in international arenas, so that their voices may be heard. Many such efforts involve genuine attempts to work together, and support and empower the latter. INGOs commonly use their funding, convening power, and access to policymaking arenas to give space to their Southern partners to engage advocacy targets. For example, during its programme Women Leadership in Peace and Security, Cordaid has opened up political space for Colombian women's organisations to push their government to embrace UNSCR 1325 (on women, peace, and security); and to include women in the peace negotiations by strategically linking a women's group with Margot Wallström, UN Secretary-General Special Representative on Sexual Violence in Conflict (Arensman et al., 2015). Another common way of providing space to 'local voices' is through facilitating Southern partners to speak at important international-level meetings (ibid).

\section{How Southern CSOs' roles can be constrained}

However, four issues potentially limit the role of Southern CSOs in evidencebased advocacy. First, considering control of access to events and meetings, and engagement with prevalent norms in specific policymaking arenas: INGOs can take up roles of gatekeepers and translators, exclusively bringing in partners that fit the kind of policy process they are engaging with, and in line with their own understandings and agendas, or those of the policymakers they target (Arensman et al., 2015, p. 470). As Keck and Sikkink (2014) explain:

The process by which testimony is discovered normally involves several layers of prior translation. Transnational actors may identify what kinds of testimony would be valuable, then ask an NGO in the area to seek out people who could tell those stories. They may filter the story through expatriates, through traveling scholars like ourselves, or through the media. There is frequently a huge gap between the story's original telling and the retellings - in its socio-cultural context, its instrumental meaning, and even its language.

(Keck and Sikkink, 2014, p. 19)

An example is provided by Gibbings (2011), who discusses how CSOs working closely with the United Nations act as mediators, bringing women from conflict zones into UN arenas as 'grounded voices' to speak on women's role in peace 
and security. Such efforts commonly involve preparation of speeches, so that the language employed by these 'grounded voices' matches discursive UN norms, e.g. framing women as agents of peace able to work across political and ethnic divisions; rather than, for example, giving space to women for expressing accusations against states, or other forms of confrontational language.

Second, and more fundamentally, INGOs' control over funding also implies considerable control over agenda-setting and thus control over which evidence matters. International funding also helps to build the research capacities of Southern CSOs in ways that support their ownership of issues and the development of advocacy (Travers, 2016). However, the way programmes are often set up 'centrally' can work against this. For example, an INGO alliance that the author worked with recently carried out a multi-country and multi-level programme on advocacy on disaster management, advocating for the integration of disaster risk reduction, ecosystems management and restoration, and climate change adaptation. Being a knowledge-intensive programme, research and evidence-based advocacy were intrinsic elements. However, with knowledge questions and aims geared towards the starting points of the programme, this also defined research priorities worldwide. Working with partners in this programme in India, the author experienced several cases of engagement with disaster problems through the prism of local social inequalities. For example, they engaged with locally marginalised groups' poor access to resources and assistance, as compared to more powerful and well-off groups. While this was accommodated, it was outside of the programme framework and knowledge questions on this front were thus not invited through the programme.

A third issue is the emphasis among many INGOs on internationally relevant issues and their resolution, e.g. leading themes such as 'climate change,' 'food security,' and 'gender.' However, this raises the question of what space remains for domestic dimensions and understandings of development issues and politics around these, with states as key actors and targets, and domestic CSOs as the more legitimate and knowledgeable advocates. A key example is that of caste, a form of social hierarchy that contributes to large-scale discrimination and deprivation in India, while largely ignored by the development sector (Mosse, 2018). While some scholars and CSOs acknowledge this role of domestic conditions and politics (Gaventa and McGee, 2010; Goodman, 2016), the need for domestic knowledge development to support this advocacy has not received much attention yet. This may easily lead to failure in addressing Southern partner organisations' knowledge needs in connection to domestic advocacy and potential opportunities. It may also lead to relegating knowledge from Southern partners to experiential knowledge, case studies, and testimonies that must fit internationally predefined programmes and theoretical frameworks.

A fourth issue concerns standards of evidence that may be imposed through aid systems. As Hayman et al. (2016, p. 153) note, 'trends in the development system are tipping the balance of knowledge conceptualization in development discourse, policy and practice towards the more scientific, normative, 
and elitist.' This can happen in ways that disqualify some forms of knowledge, raising problems of representation. Gooding (2016, p. 22) points to ongoing discussions on this that express 'concerns that the focus on research privileges issues that can be addressed through research and affects whose voices are valued.' As discussed above, such approaches may depoliticise, but here we can also point out that those advocates able and willing to abide by such imposed standards may more easily gain access to policymaking processes than those who do not.

\section{Ways forward}

The creation, interpretation, and use of evidence in evidence-based advocacy is the result of political processes between the actors involved that include the exercise of their power, the protection of organisational interests, and an important role for actors' perspectives in their ways of approaching evidence. These processes may easily lead to privileging certain types of evidence over others. While this is ostensibly portrayed in terms of evidence quality, it may lead to the exclusion of less powerful groups and marginalised interests. Some scholars and practitioners recognise that objectivity of evidence is a problematic notion, given the political dimensions of knowledge processes in policymaking, and argue we better speak of evidence-informed policymaking rather than evidence-based policymaking. Moving beyond this, from different vantage points, scholars urge us to address the problems involved, and make a turn towards more inclusiveness when it comes to engagement with actors and knowledges.

First, there are appeals to subvert current forms of domination of actors and approaches, asking to engage with local knowledge systems (Hayman et al., 2016), create space for different forms of knowledge (Gooding, 2016), and recognise the capacity of Southern civil society actors to develop their own alternative subjectivities. An illustrative example of this approach is provided by Prashant and Kapoor (2010), writing about the importance of theoretical knowledge production by a movement bringing together Dalit and Adivasi (i.e., indigenous) groups in the Indian state of Odisha, providing them with a contextually shaped understanding of the root causes of their plight and what response to their oppression should look like. Such knowledge development may be at odds with the (often more moderate) approaches of INGOs, and the question of how to engage with this is fundamental to the broader issue of how the development sector approaches development and the question what space there is for alternative understandings of development and the knowledge and knowledge development it requires.

Second, there is increasing recognition of the political nature of knowledge processes in development (see e.g. Georgalakis et al., 2017), and, in line with this, the development sector can be advised to engage more deeply with the political dimensions of knowledge creation, interpretation, and utilisation. It is important for donors and CSOs involved to recognise that these processes are 
informed by values and ideological positions, and involve questions of representation and legitimacy (Gooding, 2016; Parkhurst, 2017; Porter, 2010).

Third, the issues raised here are closely connected to the wider debate on ownership of development. It has been widely established that control over civil society as exercised by donors and INGOs acting as 'fundermediaries' has detrimental effects on the autonomy and political role of CSOs in development (Banks et al., 2015). Sector acceptance of this issue is increasingly evident. This acceptance has led to searches for solutions and some experiments involving changes in control over funding, as with the current Netherlands policy programme Power of Voices (Netherlands Ministry of Foreign Affairs, 2019), which requires Southern Partners to be part of the CSO alliances controlling the funding. Another example is the \#Shifthepower movement that started out from appeals to build CSO independence from powerful donors through community philanthropy. There are also calls to rethink INGO and donor roles, for example, proposing roles towards facilitation and support (Banks et al., 2015) and appeals to link up with existing networks and ongoing civil society processes in order to 'Start from the South' (Van Wessel et al., 2019). Also when it comes to questions around knowledge, engaging such structural conditions and embedded imaginaries, practices, and norms shaping development efforts are at the basis of the challenges, which would have to be acknowledged in order to be overcome.

\section{References}

Anderson, M. (2010). Turning evidence into policy: Challenges facing UK aid. Journal of Development Effectiveness, 2(4), 556-560.

Arensman, B., Van Waegeningh, C. and Van Wessel, M. (2018). Twinning 'practices of change' with 'theory of change' room for emergence in advocacy evaluation. American Journal of Evaluation, 39(2), 221-236.

Arensman, B., Barrett, J., Van Bodegom, A., Hilhorst, D., Klaver, D., Van Waegeningh, C. and van Wessel, M. (2015). MFS II joint evaluation of international lobbying and advocacy. Endline report. Wageningen University and Research. https://edepot.wur $. \mathrm{nl} / 356079$

Banks, N., Hulme, D. and Edwards, M. (2015). NGOs, states, and donors revisited: Still too close for comfort? World Development, 66, 707-718.

Barnes, C., Van Laerhoven, F. and Driessen, P. P. (2016). Advocating for change? How a civil society-led coalition influences the implementation of the forest rights act in India. World Development, 84, 162-175.

Barrett, J. B., Van Wessel, M. G. J. and Hilhorst, D. (2016). Advocacy for development: effectiveness, monitoring and evaluation. Wageningen University. https://edepot.wur.nl $/ 375995$

CIVICUS (2020). The state of civil society report. Available at: https://www.CIVICUS.org /index.php/state-of-civil-society-report-2020

Court, J., Mendizabal, E., Osborne, D. and Young, J. (2006). Policy engagement: How civil society can be more effective. London: Overseas Development Institute.

Development Initiatives. (2019). Global Humanitarian Assistance report 2019. Development Initiatives. Available at: https://devinit.org/publications/global-humanitarian-assista nce-report-2019/ 
Eagleton-Pierce, M. (2015). Symbolic power and social critique in the making of Oxfam's trade policy research. In: Hannah, E., Scott, J. and Trommer, S. (eds.). Expert knowledge in global trade. Routledge, 84-102.

Fransman, J. (2019). Engaging with research for real impact: The state of research in the INGO sector and ways forward for better practice. Bond.

Gaventa, J. and McGee, R. (2010). Introduction: Making change happen. Citizen action and national policy reform. In: Gaventa, J. and McGee, R. (eds.). Citizen action and national policy reform: Making change happen. London: Zed Books, 1-43.

Georgalakis, J., Jessani, N., Oronje, R. and Ramalingam, B. (2017). The social realities of knowledge for development: sharing lessons of improving development processes with evidence. IDS/The Impact Initiative.

Gibbings, S. L. (2011). No angry women at the United Nations: Political dreams and the cultural politics of United Nations Security Council Resolution 1325. International Feminist Journal of Politics, 13(4), 522-538.

Goldman, I. and M. Pabari (eds.). (2021). Using evidence in policy and practice. Lessons from Africa. Abingdon: Routledge.

Gooding, K. (2016). What do we mean by evidence-based advocacy? Ideas from NGOs in Malawi. In: Hayman, R., King, S., Kontinen, T. and Narayanaswamy, L. (eds.). Negotiating knowledge: Evidence and experience in development NGOs. Rugby: Practical Action Publishing, 129-145.

Goodman, E. S. (2016). Changing advocacy practices in a changing world: An evaluation of Oxfam America's influencing work in a shifting international NGO culture. Available at: https://digitalcollections.sit.edu/capstones/2884/

Gourevitch, P. A., Lake, D. A. and Stein, J. G. (eds.) (2012). The credibility of transnational NGOs: When virtue is not enough. Cambridge: Cambridge University Press.

Hayman, R. (2016). NGOs and the evidence-based policy agenda. In: Hayman, R., King, S., Kontinen, T. and Narayanaswamy, L. (eds.). Negotiating knowledge: Evidence and experience in development NGOs. Rugby: Practical Action Publishing.

Hayman, R., King, S., Kontinen, T. and Narayanaswamy, L. (eds.) (2016). Negotiating knowledge: Evidence and experience in development NGOs. Rugby: Practical Action Publishing.

Hivos (2016). Case study for Sumba Iconic Island Programme. Available at: https://www.hiv os.nl/assets/2016/06/CD-case-study-Sumba-Island.pdf

Jordan, L., \& van Tuijl, P. (1998). Political Responsibility in NGO Advocacy: Exploring emerging shapes of global democracy. New York: Europe's Forum on International Cooperation.

Keck, M. E. and Sikkink, K. (1999). Transnational advocacy networks in international and regional politics. International Social Science Journal, 51(159), 89-101.

Keck, M. E. and Sikkink, K. (2014). Activists beyond borders: Advocacy networks in international politics. Cornell University Press.

Keeley, J. and Scoones, I. (2014). Understanding environmental policy processes: A conceptual map. In: Keeley, J. and Scoones, I. (eds.). Understanding environmental policy processes: Cases from Africa. Routledge, 21-39.

Mably, P. (2006). Evidence based advocacy: NGO research capacities and policy influence in the field of international trade. Available at: https://idl-bnc-idrc.dspacedirect.org/bitstream /handle/10625/45959/132438.pdf?isAllowed=yandsequence $=1$

Mayne, R., Green, D., Guijt, I., Walsh, M., English, R. and Cairney, P. (2018). Using evidence to influence policy: Oxfam's experience. Palgrave Communications, 4(1), 1-10.

Mosse, D. (2018). Caste and development: Contemporary perspectives on a structure of discrimination and advantage. World Development, 110, 422-436. 
Motta, S. and Nilsen, A. G. (eds.) (2011). Social movements in the global south: Dispossession, development and resistance. London: Palgrave McMillan.

Netherlands Ministry of Foreign Affairs (2019). Grant instrument Power of Voices partnerships. Available at: https://www.rijksoverheid.nl/documenten/beleidsnotas/2019/11/28/b eleidskader-versterking-maatschappelijk-middenveld

Oxfam (2019). Creating killer facts and graphics. Available at: https://policy-practice.oxfam. org.uk/publications/creating-killer-facts-and-graphics-253013

Parkhurst, J. (2017). The politics of evidence: From evidence-based policy to the good governance of evidence. Routledge.

Porter, C. (2010). What shapes the influence evidence has on policy? The role of politics in research utilisation. Young Lives. Available at: https://www.younglives.org.uk/content/what -shapes-influence-evidence-has-policy-role-politics-research-utilisation

Prasant, K. and Kapoor, D. (2010). Learning and knowledge production in Dalit social movements in rural India. In: Learning from the ground up. London: Palgrave Macmillan, 193-210.

Rodriguez, R. M. (2010). On the question of expertise: A critical reflection on 'civil society' processes. In: Choudry, A. and Kapoor, D. (eds.). Learning from the ground up. London: Palgrave Macmillan, 53-68.

Storeng, K. T. and Béhague, D. P. (2014). 'Playing the numbers game': evidence-based advocacy and the technocratic narrowing of the safe motherhood initiative. Medical Anthropology Quarterly, 28(2), 260-279.

Stroup, S. S. and Wong, W. H. (2017). The authority trap: Strategic choices of international NGOs. Ithaca: Cornell University Press.

Tallberg, J., Dellmuth, L. M., Agné, H. and Duit, A. (2018). NGO influence in international organizations: Information, access and exchange. British Journal of Political Science, 48(1), 213-238.

Thrandardottir, E. (2016). Legitimacy and knowledge production in NGOs. In: Hayan, R., King, S., Kontinen, T., Narayanaswamy, L. (eds.). Negotiating knowledge: Evidence and experience in development NGOs. Rugby: Practical Action Publishing, 47-58.

Travers, S. (2016). Canadian civil society organizations using research to influence policy and practice in the Global South. In: Mougeot, L. J. A. (ed.). Putting knowledge to work: Collaborating, influencing and learning for international development. Rugby: Practical Action Publishing, 107-142.

Van Wessel, M. G. J., Katyaini, S., Mishra, Y., Naz, F., Balasubramanian, R., Manchanda, R., ... and Sahoo, S. (2019). Civil society dynamics: Shaping roles, navigating contexts. Wageningen University and Research. Available at: https://library.wur.nl/WebQuer y/wurpubs/fulltext/511476

Van Wessel, M., Schulpen, L., Hilhorst, T. and Biekart, K. (2017). Mapping the expectations of the Dutch strategic partnerships for lobby and advocacy. Wageningen University and Research. Available at: https://edepot.wur.nl/410800

Weible, C. M. (2008). Expert-based information and policy subsystems: A review and synthesis. Policy Studies Journal, 36(4), 615-635. 


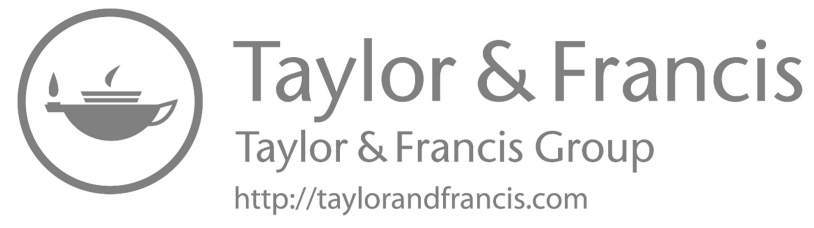

